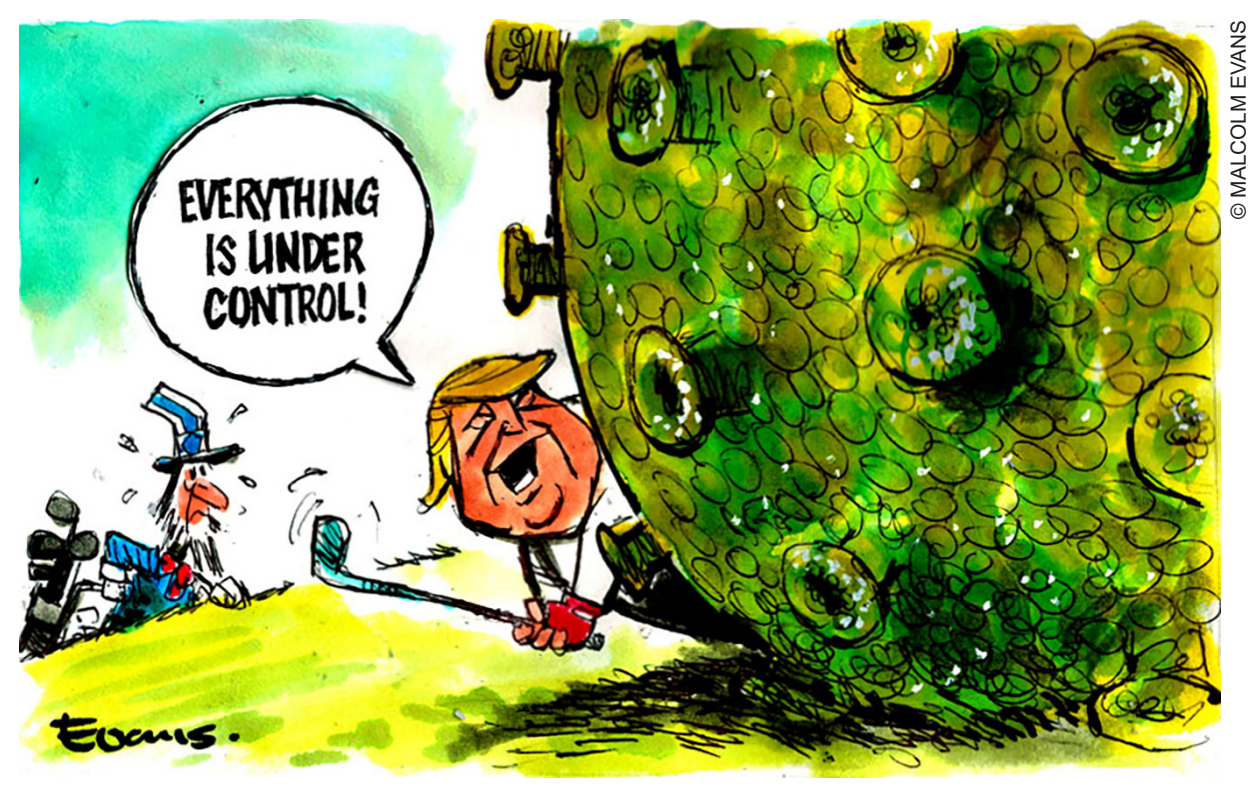

\title{
EDITORIAL: Under the pandemic siege
}

$\mathrm{T}$ IS possible that future generations will think that $\mathrm{BC}$ stands for Before Coronavirus - and possibly that AD stands for After the Donald.

All joking aside, here in Aotearoa New Zealand we have been far luckier than most countries, with early and decisive action by Prime Minister Jacinda Ardern and her advisers rapidly bringing the pandemic threat under control. Several Island nations remain COVID-free, thanks again to early intervention and strong measures, including border control.

In countries which did not react properly, the results have been catastrophic. The Centre for Disease Control and Prevention (CDC, 2019) has predicted that the appalling death toll in the United States will reach and possibly surpass 250,000 by the time Donald Trump is finally ejected from the White House.

Comparatively safe as we are in New Zealand, this is still the second edition of Pacific Journalism Review we have produced with COVID-19 in the background and even when the pandemic is over, or at least brought under control, we will still be threatened by a host of challenges - not least that of climate change, which has already forced internal migration in Papua New Guinea and Fiji and threatens to do the same in the ASEAN region, with its incomparably larger population.

It was significant that the first national leader to congratulate US Presidentelect Joe Biden was Fijian Prime Minister Voreqe Bainimarama (Roche, 2020), who tweeted: 'Together, we have a planet to save from a \#ClimateEmergency and a global economy to build back better from \#COVID19. Now, more than 
ever, we need the USA at the helm of these multilateral efforts (and back in the \#ParisAgreement-ASAP!)'

This edition of PJR therefore focuses on the theme of 'Climate crisis and Coronavirus' and is linked to the 'Rethinking the Social World' online symposium on Social Sciences 2020 in Yogyakarta, Indonesia, on August 24-25. This is a biennial international event organised by the AUT Pacific Media Centre's partner Centre for Southeast Asian Social Studies (CESASS) at the Universitas Gadjah Mada. The theme of the symposium, held in partnership with the PMC, addressed the changes that communication and information technology has brought to societies in the Asia-Pacific. We are grateful to our co-editor for this edition, Dr Hermin Indah Wahyuni from UGM for co-ordinating papers from the symposium.

The articles in our Themed Section are drawn from papers presented at the symposium and which reflect current research and thinking on related topics in the ASEAN region. The section begins with Pauline Gidget Estella's investigation of how good journalists are at interpreting and disseminating technical or scientific information in a time of crisis. These skills are vital if people are to make informed decisions in a time of global crisis.

She is joined by Anggita Marthin and Louis Budiman, who argue that ASEAN governments have by and large, been unprepared to deal with migration caused by climate change. The situation is complicated because of the unresolved debate about the legal status of such migrants.

Lidwina Mutia Sadasri examines how the Indonesian government used two social influencers, @dr.tirta and @rachelvennya, to deliver information about COVID-19, a response taken amid an absolute maelstrom of misinformation, conspiracy theories and wild speculation on the internet.

Laila Alfirdaus examines how the Indonesian bureaucracy politicises environmental evaluations in resource-dependent areas, applying minimum standards, but sometimes co-opting NGOs when outcomes might offend powerful interests.

Philip Cass looks at the role of mainstream churches in facing climate change challenges in the Pacific and argues that they need to be understood not just as super-NGOs, but organisations driven by profound religious beliefs. This article was the basis of an online presentation to the Third Pacific Climate Change Conference in Apia, Samoa, in October 2020.

Akhteruz Zaman and Jahnnabi Das consider how various policy advocates have attempted to influence public discourses about climate displacement in Oceania by examining policy documents and newspaper articles in Fiji and New Zealand. They find quite distinct discourses emerging in both countries.

Mohamad Saifudin Mohamad Saleh and Harald Heinrichs investigate the types of environmental issues represented in Malaysian newspapers and Environmental Non-Governmental Organisation (ENGOs) newsletters. An examination of factors in the selection of stories by both social actors finds that on 
both sides, story selection is often driven by similar criteria.

Our Frontline section begins by looking at a significant shift in research classifications. The Australian and New Zealand Standard Research Classification (ANZSRC) 2020 decision on disciplinary categories has profound implications for journalism as a research discipline, confirming it as a sovereign discipline distinct from communication and media studies. Chris Nash analyses the impact this change could have.

Frontline editor Wendy Bacon reviews the life and achievements of campaigner and journalist Jill Emberson, focusing on her work with ABC Radio's feminist Coming Out Show and Ties that Bind, which looked at Tonga and the Tongan diaspora in Australia.

Norman Zafra examines how political documentary embodies the traits and functions of alternative journalism though Obrero ('worker'), his documentary project about Filipino workers who came to New Zealand after the Christchurch earthquake.

Continuing our coronavirus theme, editor David Robie and Sri Krishnamurthi deconstruct a four-month 'Coronavirus Plus' initiative conducted by the Pacific Media Centre at AUT in response to the pandemic, using the Asia Pacific Report website, asiapacificreport.nz, as the publishing platform.

As a reminder that serious problems continue behind the pandemic, our Unthemed Section looks at issues of racism in Australia, oppression of West Papuans and the political implications of the internet in the Pacific.

Nearly 30 years after the release of the report of the Australian Royal Commission into Aboriginal Deaths in Custody, Bonita Mason builds on Wendy Bacon's seminal 2005 work to report on how Australian journalists have covered Aboriginal deaths.

The internet continues to develop as a means of binding diasporic Pacific communities together and in this article Rufino Robert Varea, Jason Titifanue, Romitesh Kant and Renata Varea examine how it has allowed Rotumans in Fiji to inform and educate themselves and their networks about political issues of Rotuman interest.

The oppression and harassment of West Papuans, so often reported in these pages, goes on unabated as Justito Adiprasetio reports in this examination of the aftermath of an attack on a West Papuan student dormitory in East Java in August 2019.

Levi Obijiofor and Shailendra Singh offer interview-based insights into how Indian journalists in the world's largest democracy are coping with major economic, technological and political developments, including digital disruptions and other pressures under Prime Minister Narendra Modi's 'Hindutva' government.

'Eve-teasing' is a euphemism for street-based sexual harassment, and Rajoanna Mowly and Nasya Bahfen analyse this widespread issue impacting on the emotional, mental, and physical wellbeing of Bangladeshi women. The authors conclude the media can play a vital role with coverage and by raising awareness. 
Finally, our Reviews Section features another selection of books we think will interest you, including publications on the current crisis in the industry by expatriate New Zealand journalist-turned academic Mel Bunce, BBC broadcaster John Humphrys' autobiography, an account of reporting on the decades of war in the Middle East by veteran Arab-New Zealand journalist Tuma Hazou and poetry written during the coronavirus lockdown.

Regular contributor Lee Duffield leads off with a timely review of a new book arguing that journalists need to implement new ways of reporting on race as the United States is racked by violent racial clashes and the demands of the Black Lives Matter movement have spread globally.

Elsewhere in this section, editor David Robie tackles two thought provoking books by Kalinga Seneviratne on the myth of truth in journalism and new ways of practising the profession using mindfulness.

Pacific affairs journalist Michael Field is in charge of this edition's Bookshelf, musing on the virtues of Herman Melville and recalling conversation with Epele Hau'ofa, author of the classic Tales of the Tikongs.

\section{Sabbatical}

After more than 26 years of publication, PJR is taking a sabbatical. Founded by our editor, Professor David Robie at the University of Papua New Guinea in 1994, PJR has travelled across the ocean to the University of the South Pacific in Fiji and then to Auckland University of Technology.

Along the way we have established a strong presence in the academic marketplace, scoring extremely well across a range of academic publication indicators and providing space for voices from Asia, Australia and the Pacific as well as New Zealand.

This year we have produced two large volumes, both over the 300-page mark. Both have reflected international collaborations with academics and journalists in the Pacific, Asia and Australia and have brought together an enormous range of interests, opinions and ideas.

After all that effort, it is time to recharge our batteries and take some time to plan for the next phase in our development. David is standing down as editor and our current associate editor, Philip Cass, has taken up the reins. We look forward to reuniting in the future.

\section{DR PHILIP CASS}

Editor

Pacific Journalism Review

www.pjreview.info 
IN NOVEMBER 2020, when Joe Biden finally ushered in his presidency pledges amid the narrow triumph in the swing state of Pennsylvania, he wasted no time in adding to his modest twitter output, just like his predecessor Donald Trump. Three days earlier the President-elect had fired off a tweet to renew a promise that the United States would rejoin the 2015 Paris Agreement, marking the end of a four-year assault on climate protections under Trump's leadership. Ironically, the tweet was on the very day that the Trump Administration officially abandoned the Paris Climate Accord (Farand \& Gerretsen, 2020).

'And in exactly 77 days,' he tweeted, 'a Biden administration will rejoin it.'

The Paris Agreement requires all countries to present new or improved climate targets to the UN. As the world's second highest greenhouse gases emitter (after China), the US is critical to meeting the Paris of limiting the global heating "well below $2^{\circ} \mathrm{C}$ " and to target even lower to $1.5^{\circ} \mathrm{C}$.

Elected on the most ambitious climate platform ever presented by a presidential candidate (and gaining more than 77 million votes, the most ever), Biden pledged a $\$ 2$ trillion 'clean air revolution'. The journey ahead will be rocky and frustrating. The remnants of Trumpism and an obstructive outgoing administration will provide many barriers.

This journal is producing its third edition based on climate change (albeit complicated by the coronavirus pandemic) following the 'Climate change in Asia-Pacific' special edition produced in mid-2017 and the 'Disasters, cyclones and communication' issue in mid-2018. It has a strong commitment to human rights and environmental studies in a media and journalism context.

However, the current climate and health challenges are being addressed against the backdrop of a so-called post-truth world that is playing out in the AsiaPacific region as critically as elsewhere, including the US. Issues of conspiracy theories, disinformation and hoaxes had such an impact on the fringes of the New Zealand election in October that commentators such as RNZ Mediawatch's Colin Peacock were driven to ask: 'Should we fear fake news in our politics?'

Based on the experience of the US elections in 2016 and beyond and the Brexit debacle and an avalanche of 'fake news' in later ballots in Australia, France and other countries, concerns were high. As it turned out, 'fears that foreign political consultants and fringe parties would turn Facebook followers and fake news in the [New Zealand] election proved unfounded' (Peacock, 2020). However, while New Zealand's major parties also 'mostly ran a clean game online', Peacock pointed to the online misinformation that was mostly about COVID-19 and to New Zealand research linked to the Digital Election Campaigning Worldwide project with warnings about the future risks.

Four years in the White House by a president globally regarded as a serial liar has 'accelerated the drift towards post-truth, and the media is shackled to that acceleration', writes Guardian political editor Katharine Murphy, who has 
raised critical questions about the role and responsibilities of journalists and journalism when dealing with fact-checking and known untruths. In response to major networks pulling the plug on a presidential 'florid fantasy' about fake votes and fake polls in the wake of the US election, she had this to say:

Faced with this reality - a lying, dangerous demagogue openly hostile to political conventions and democratic norms - media outlets face difficult choices. Do networks refuse to broadcast the lies? Do media outlets disrupt the tirades with live fact-checking? Broadcast the news (and a president speaking meets the news test) without interruption, but put straps at the bottom of the screen alerting viewers to form their own conclusions? (Murphy, 2020)

As she says, 'puncturing self-serving propaganda' is the primary duty of serious journalists. Over the past 26 years, Pacific Journalism Review has done its fair share of 'puncturing' and bringing critical issues before our media fraternity, both through more than 1000 research articles published, and its range of critical reviews and actual journalism (especially through our Frontline section pioneered by Wendy Bacon).

Founded at the University of Papua New Guinea in 1994, the journal has also had a five-year stint at the University of the South Pacific, but its longest home has been 18 years at Auckland University of Technology. In the wake of our 20th anniversary celebration at AUT six years ago, colleague and friend Lee Duffield wrote a reflective article for our birthday edition in which he concluded that $P J R$ had always emphasised its 'regional identity'. PJR has been, he added, dedicated to

Adopting its own 'Pacific' style of discourse and inquiry, [f]or 20 years it has been focused on Pacific issues, for and by people and institutions of the region-while always open to linkages and inputs from major global centres. (Duffield, 2015).

As this has been a transitional and final edition for me as founding editor at the helm and in the 'frontline', it is an opportunity to thank and acknowledge many people who have contributed and shared with me on this waka voyage. Some of them are featured in a 2014 birthday cartoon by Malcolm Evans and others have joined since or been involved earlier. First, Philip Cass, who is taking over as editor. I am delighted that Philip is taking on this challenge as he was with us as a wantok from Wewak, Papua New Guinea, contributing right from the beginning in Port Moresby. He has also been a dedicated and voluntary reviews editor and associate editor for the past seven years.

Del Abcede has been the designer since the embryonic Pacific Media Centre was launched in 2007 and took over as the publishing 'umbrella' from AUT's 


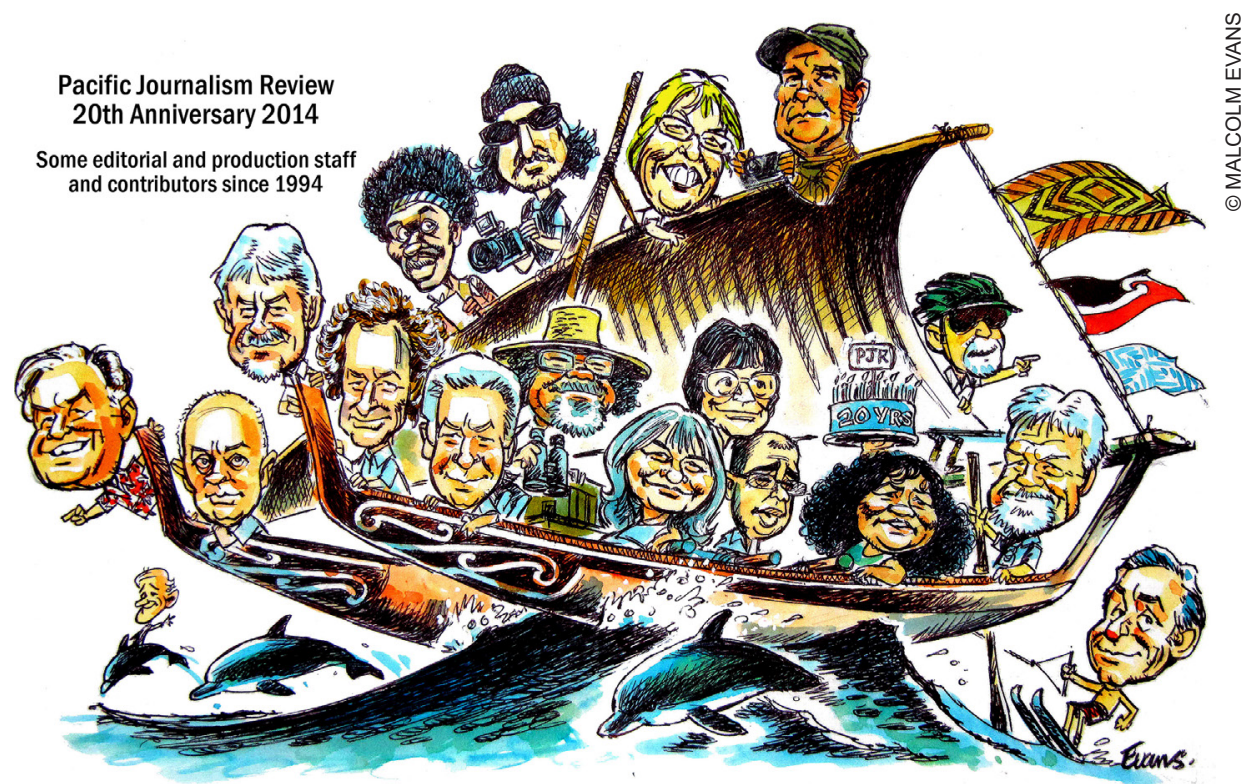

School of Communication Studies. She has carried the burden and stress of hours and nights of endless layouts to meet the never-ending deadlines.

A tribute to mentors Wendy Bacon, Chris Nash, Trevor Cullen, Mark Pearson, Pat Craddock, Lee Duffield and Shailendra Singh. They are all in the cartoon. So too are Campion Ohasio, Ben Bohane, Allison Oosterman, John Miller, Tui O'Sullivan, Kevin Upton, Barry King and cartoonist Evans is riding a dolphin.

Not pictured in the cartoon are others who have contributed in various editorial roles such as Khairiah A. Rahman, Peter Cronau, Nicole Gooch, Camille Nakhid, Heather Devere, Jim Marbrook, Joseph Fernandez, Evangelia Papoutsaki, Susan O'Rourke Alan Samson, Murray Horton, Linnea Eltes, Eric Loo, Ian Richards, John Henningham, Martin Hadlow, Sandra Kailahi, Alex Wake, Kayt Davies, James Hollings, Danilo Arao, Sasya Wreksono, Kalafi Moala, Crispin Maslog, Ramon Tuazon, Daya Kishan Thussu, Fernando Sepe Jr, Mariquit Almario-Gonzales, Belinda Lopez, Johnny Blades, Ian Stuart, Alex Perrottet, Sitiveni Ratuva, Faith Valencia-Forrester, Kasun Ubayasiri, Alan Robson, Angela Romano, Katheryn Bowd, Hermin Indah Wahyuni, Andi Fitrah, Vissia Ita Yulianto, Victor Mambor, Scott MacWilliam, Tony Clear and also our manager Edelita Clark. Plus our Tuwhera digital support team Luqman Hayes and Donna Coventry. Thank you all (and anybody I have inadvertently overlooked) for the contribution over the years, as a journal like this relies on considerable teamwork and an enormous amount of voluntary input.

Part of the Pacific Journalism Review story has been told in a YouTube video by AUT screen production graduate Sasya Wreksono (2014), who interviewed 
several of our contributors and editors on both sides of the Tasman. At the time of our 20th anniversary, I wrote what I will echo today in that over our more than two decades 'we have achieved precisely what we set out to do, being a critical conscience of Asia-Pacific socio-political and development dilemmas'.

Tenk yu tumas ... lukim yu, Philip, and good luck to you and your future crew for the media waka journey ahead.

\section{DAVID ROBIE \\ Founding Editor \\ Pacific Journalism Review \\ www.pjreview.info}

\section{References}

CDC — Centre for Disease Control and Prevention (2019). Covid-19 Forecasts: Deaths. Retrieved from https://www.cdc.gov/coronavirus/2019-ncov/covid-data/forecastingus.html

Duffield, L. (2015). Pacific Journalism Review: Twenty years on the front line of regional identity and freedom. Pacific Journalism Review: Te Koakoa, 21(1), 18-33. https:// doi.org/10.24135/pjr.v21i1.145

Farand, C., \& Gerretsen, I. (2020, November 7). Joe Biden wins the White House, in pivotal moment for global climate action. Climate Change News. Retrieved from https://www.climatechangenews.com/2020/11/07/joe-biden-wins-white-housepivotal-moment-global-climate-action/

Peacock, C. (2020, October 25). Should we fear fake news in our politics? RNZ Mediawatch. Retrieved from https://www.rnz.co.nz/national/programmes/mediawatch/audio/2018769801/should-we-fear-fake-news-in-our-politics

Robie, D. (2015). EDITORIAL: Two decades of critical inquiry. Pacific Journalism Review: Te Koakoa, 21(1), 7-14. https://doi.org/10.24135/pjr.v21i1.143

Roche, D. (2020, November 7). Fiji's Prime Minister appears to become first world leader to congratulate Biden on election. Retrieved from https://www.newsweek.com/ fiji-prime-minister-first-world-leader-congratulate-biden-election-1545725

Wreksono, S. (2014). The life of Pacific Journalism Review [Short documentary]. Available at https://www.youtube.com/watch?v=Brq_AgBS-ys 